\title{
Making Transportable Identities Relevant as a Persuasive Device. The Case of Hillary Clinton's 2008 Concession Speech
}

\begin{abstract}
Transportable identities are often extraneous in discourse, but they can be brought to the surface and made relevant, also as a means to persuade an audience. I discuss the case of the concession speech Hillary Rodham Clinton gave on June, $7^{\text {th }} 2008$ after she lost against Barack Obama in the Democratic Primaries. In order to successfully reposition herself from an opponent to a supporter of Obama, Clinton draws on several aspects of her transportable identity to stress the similarity between herself and Obama. Next to focusing on the fact that they are both Democrats, Americans and human beings, she zooms in on their membership of two powerless groups: namely that of women and African Americans. Both from a historical and a personal perspective, these two categorizations of herself and Obama are presented in a highly persuasive way and create unity between the two former opponents. As such, I not only show how identity, which relates to the concept of ethos in classical rhetorical terms, is discursively constructed in a speech, but also how it serves the argumentational goal of repositioning oneself entirely.
\end{abstract}

\section{Introduction}

In the past few years, the study of "identity ha[s] moved into the center-stage of the social sciences” (Bamberg et al. 2007: 1), but, since it developed from different traditions, there are quite diverging perspectives on the way identity is viewed and analyzed. An important - and by now generally shared - perspective though, is that of social constructionism, which has led linguists to view identity as a social construct. So instead of taking an essentialist perspective on identity and "directly contrary to what appears to be its settled semantic career" (Hall 2000: 17), "role and identity are not regarded as fixed categories but as resources which actors draw on to carry out everyday lives" (Hall et al. 1999: 293) and they are "continually shaped and reshaped through interactions with others and involvement in social and cultural activities" (Wetherell / Maybin 1996: 220). Or as Verschueren (2008: 26) sums it up:

[...] identity is not a property [...] of an individual, but [...] it is interactively created over and over (though with a degree of consistency), so that the same individual can literally have different identities in different contexts.

So instead of looking at identity as "a given" or "a product", we have to view it as "a process" (De Fina et al. 2006: 2). This, of course, makes identities "extremely complex construct[s]" (De Fina 2003: 15), which are typically viewed in the plural since "individuals have multiple identities" (Verschueren 2008: 26) because of their evolving and contextually bound nature. These identities may even shift during one interaction, and they can be negotiated and renegotiated on a turn-byturn basis.

In his study of the way people can construct these different identities, Zimmerman discerned three levels of identity, namely (1) discourse identities, (2) situated identities and (3) transportable identities (Zimmerman 1998: 90). The first level refers to the discourse roles people can have in a conversation, like for instance speaker/listener. The second level of situated identities indi-

\footnotetext{
* Dorien Van De Mieroop

Lessius/KULeuven

Sint-Andriesstraat 2

B-2000 Antwerpen

Belgium

dorien.vandemieroop@lessius.eu
} 
cates the specific roles that "are rendered relevant in specific settings" (Zimmerman 1988: 426), for instance the role of patient in a doctor-patient interaction. Finally, the transportable identities (which have also been called "master identities" (Zimmerman 1988: 426) or "categorical identities" (Zimmerman 1992: 51)) are "potentially relevant anytime, anywhere" (Zimmerman 1988: 426) and refer to particular characteristics of individuals, such as age, sex and race, "that are potentially usable across all social situations” (Zimmerman 1992: 51). Interestingly, participants in an interaction can make this third level of identity relevant by discursively referring to these characteristics, but - contrary to the view from an essentialist perspective - these can be totally irrelevant in an interaction as well. For example, in particular situations people can make a transportable characteristic such as their gender (or the gender of other interlocutors) relevant in an interaction, while in other situations this characteristic may not be drawn upon. Furthermore, such transportable identities can be referred to selectively and carefully, since, as Schiffrin stated: "we may act more or less middle-class, more or less female, and so on, depending on what we are doing and with whom" (Schiffrin 1996: 199) and they may interfere with other levels or different aspects of identity construction. A good example of the complex, negotiated and fluid nature of these identity constructions in everyday conversation can be found in Georgakopoulou's analysis of small stories (2007), in which she describes the relations between "storytelling roles and larger identities" as "not unidirectional but dialectically and dynamically evolving" (Georgakopoulou 2007: 106).

\section{Research questions}

In this article, I look into the way elements from the transportable identity of an individual can be referred to in a specific form of communication that is largely prepared, namely speeches. I have previously shown that different identities can be invoked in informative speeches (Van De Mieroop 2005, 2007 and 2008), but this time I focus on a different subgenre, namely political speeches. For this topic, I draw on the work of De Fina (1995), who focused on the analysis of pronouns in semi-prepared political discourse. In particular, she argued that: "Pronominal choice is $[\ldots]$ seen $[\ldots]$ not so much as a variable related to speaker's style, but as a coherent indication of the speaker's presentation of self.” (De Fina 1995: 382), as such establishing a link between the use of pronouns and identity construction within a political data set. (I will come back to the importance of pronouns in the analyses section of this article.)

Furthermore, I ask myself the question to what extent these elements of transportable identity can be strategically drawn upon as argumentative devices. For this purpose, I want to relate my discourse analytical approach to identity to the findings of ancient rhetoric. This is a relatively obvious choice, since political speeches are often highly rhetorical and already in ancient rhetoric, the element of identity was identified as a potential argumentative device under the term ethos. This is nested in the framework of the three traditional forms of argumentation as have been described by Aristotle (4th century BC), namely logos (factual arguments), ethos (arguments related to the person of the speaker) and pathos (emotional arguments). This concept of ethos was operationalized by three aspects, namely good sense, good character and goodwill. This relates directly to Linde's findings concerning the construction of identity in narratives, namely that narrators want to be perceived as good people whose lives were characterized by coherent choices (Linde 1993),as such thus trying to come across as people with good sense and good character, which are two important aspects of ethos. However, in spite of its clear link, relating the socialconstructionist concept of identity to a rhetorical concept such as ethos is not entirely unproblematic either. This is mainly due to the relatively deterministic nature that is often attributed to rhetoric, or as Johnstone formulates it in her discussion of the link between rhetoric and the 'linguistic individual':

Rhetoric is often seen as a set of options or possibilities among which rhetors choose for strategic reasons having to do with topic, audience and so on. What Aristotle called the "art of persuasion" is sometimes taught as if it involves no more than learning to assemble discourses from rhetorical Erec- 
tor Sets of options for lines of argument, modes of organization, and methods of delivery. (Johnstone 1996: 90)

This general perception of the predefined nature of rhetoric is of course not acceptable from a social-constructionist point of view, but, as Johnstone continues, it is still possible to introduce rhetoric in the discourse analytical study of identity as long as one keeps the following in mind:

\begin{abstract}
A model of rhetorical discourse that is adequate as an explanation must be a model in which the choices a speaker makes are understood as having to do with the adaptation to a situation, not of a set of preexisting options but of a personal voice. (Johnstone 1996: 90)
\end{abstract}

And it is exactly the construction of this "personal voice", as an "adaptation to a [very particular (own addition)] situation" that forms the focus of this article, which as such aims to integrate an argumentative aspect, by means of the rhetorical concept of ethos, in the discourse analytical study of identity.

\title{
3. Data
}

The data I study consist of a single case, namely the concession speech Hillary Rodham Clinton gave when she ended her own campaign for the Democratic presidential nomination in the 2008 election and endorsed Barack Obama as the next presidential candidate on June, $7^{\text {th }} 2008$ in Washington. The speech is 29 minutes long and consists of 3109 words. For analytical clarity and for the reader to have insight in the chronology of the examples, I numbered the lines and the entire speech consisted of 323 lines. The speech itself can be viewed on YouTube (http://www.youtube. com/watch?v=zgi_kIYx_bY) - last consulted on March, 11 ${ }^{\text {th }}$ 2009).

This speech is particularly interesting because its main goal was for Clinton to reposition herself entirely, namely moving from an opponent of Barack Obama in "one of the most competitive and most exciting primary races in United States history" (Wikipedia 2009a), to a supporter of Barack Obama as the democratic candidate for presidency. Clinton's whole process of repositioning was thus initiated by this concession speech, and interestingly, history demonstrated that this repositioning process was very successful, since Hillary Rodham Clinton became United States Secretary of State in the president's cabinet after Barack Obama became president on January $20^{\text {th }}, 2009$.

\section{Method}

In this speech, I analyze the way Clinton manages to reposition herself and I focus on the ethosaspect of her argumentation. In particular, I discuss the way she presents herself and constructs her identity. However, identity analysis is not a clear-cut matter, as Ochs already indicated when stating that "the relation between language and social identity is predominantly a sociolinguistically distant one" (Ochs 1993: 288). Thus it is necessary to integrate different elements into the analysis to grasp the construction of identity. De Fina (2003: 23) discerns three levels:

\footnotetext{
The lexical level refers to the use of specific words or expressions. The textual pragmatic level refers to textual logical and argumentative relationships both explicit and implicit. The interactional level refers to the devices and strategies used by narrators to index their stances and attitudes both towards their own texts and other interlocutors.
}

Only some of the final aspects which explicitly deal with interactional elements ${ }^{1}$ are not taken into account here, since this speech was monologic and no real interaction could be discerned, except for the audience's applause or laughter. This is however not the focal point of this analysis and thus I disregard it further. Furthermore, also other aspects of the actio or pronuntiatio (in classi-

1 The term "interactional elements" has to be understood quite literally here and refers to typical elements of the interaction, like for instance overlap and repair, which may be indexical of identity construction as well but which are irrelevant here because of the monologic nature of the speech. Of course, an element such as the speaker's stance towards her audience is very important in this dataset and will thus be taken into account as well. 
cal rhetorical terms, see for instance Andeweg/De Jong 2004: 24) are not taken into consideration, since that would demand an entire study in its own right - elements such as body language, intonation and appropriate pausing are of course of the utmost importance for the efficiency of the delivery of a speech, but these require so much attention that it would only divert the reader away from the focal point of this study. Therefore, the analyses only focus on the content and the particularities of the formulation (in classical rhetorical terms, the invention, disposition and elocution, see also for instance Andeweg/De Jong 2004: 23-24).

Furthermore, since Clinton has to shift her own status from opponent to supporter of Obama, she will have to 'reposition' herself in this speech. Regarding 'positioning', I draw on Bamberg's three levels of positioning, which focus on the following questions:

1. How are the characters positioned in relation to one another within the reported events?

2. How does the speaker position him or herself to the audience?

3. How do narrators position themselves to themselves? (Bamberg 1997: 337)

These three levels are intertwined with one another, since it is through positioning characters and oneself towards an audience (levels 1 and 2), that the speaker is actually also constructing his/her identity (level 3). In the analyses, I also incorporate these levels so that a general insight is created into how the speaker is able to successfully execute her own "repositioning", by which I mean the way Clinton shifts her position towards Obama (who is a very important character in this corpus - level 1) and to the audience (from potentially a presidential candidate to a 'regular' member of the Democratic party - level 2), which leads to a repositioning of herself (from opponent to supporter - level 3). In particular I focus on the question how the speaker draws on elements of her transportable identity as a persuasive device in this repositioning process, which of course in real life extended beyond this particular speech only.

\section{Analyses}

In these analyses, I only highlight the fragments that support Clinton's repositioning to an adherent of Obama. I am thus not presenting a complete analysis of the argumentation of the speech, which is beyond the scope of this article. Instead, I look at some of Clinton's self-presentations and positioning shifts that are prominent in the speech. Throughout the speech, Clinton implicitly self-categorizes herself quite often. Self-categorizations have been defined as important means to support identity construction(e.g. see De Fina 2003) and they often also invoke a group identity which can be a highly persuasive device.

\subsection{Family metaphor}

From the start of the speech onwards, Clinton re-establishes the group identity of the Democrates as opposed to the Republicans. As such, she downplays the opposition within the Democratic party, consisting of her own supporters opposed to those of Obama, which had been the focal point beforehand. The construction of such binary us-them oppositions has been illustrated as an important membership categorization device (MCD), for example by Leudar et al.'s analysis of the speeches of Bush, Blair and Bin Laden after the 9/11-attacks (Leudar et al. 2004), which can strongly support the construction of a group identity. This needs to be shifted entirely now, and Clinton does this by using a metaphor. However, because of the tough character of the Primary race with Obama, Clinton explicitly acknowledges this fact, but then establishes group identity by means of a powerful metaphor, namely that of the family (lines 95-96).

(1)

89 Now when I started this race, I intended to win back the

90 White House, and make sure we have a president who puts

91 our country back on the path to peace, prosperity, and progress. 
92 And that's exactly what we're going to do by ensuring that

93 Barack Obama walks through the doors of the Oval Office

94 on January 20, 2009.

95 I understand that we all know this has been a tough fight.

96 The Democratic Party is a family, and it's now time

97 to restore the ties that bind us together and to come together

98 around the ideals we share, the values we cherish, and the country we love.

Initially, Clinton still speaks on behalf of herself, as is demonstrated by her use of the first person prounoun (I) in line 89. Also by voicing her goal as her intention to win back the White House, she not only refers to the general goal to get a Democrat to become the next president, but she also implicitly refers to her time as a First Lady at the White House, thus already preparing her identity construction as an experienced woman (see below). She then immediately links that to the chance that Obama will become the next president without providing any supporting arguments. She shifts to the inclusive we-form, that refers to all the Democrats and thus she already implicitly re-establishes the group-identity of all the Democrats. The argument for this is given afterwards, from line 95 onwards: she starts by honestly admitting the toughness of the fight (line 95), which she implies is well-known by means of the extreme case formulation (Pomerantz 1986) we all know. She then introduces a metaphor, a rhetorical device which "has long been recognized as important in political rhetoric" (Chilton 2004: 51) since it is "simple and highly complex at the same time" (Seidl 2003: 173). Lakoff characterizes the metaphorical functions of "highlighting and hiding" (Lakoff/Johnson 1980: 10) as follows: "What metaphor does is limit what we notice, highlight what we do see, and provide part of the inferential structure that we reason with" (Lakoff 1991). This family metaphor is quite a stereotypical metaphor which underlines the close ties within and unity of the party. And as everybody knows, in every family there are quarrels every now and then, but these do not overrule the unitary character of the close bonds between its members, which is elaborated upon in lines 96-98. The three part list that closes this section is a typical way to imply covering the whole ground (Potter et al. 1991) and elicit applause from the audience (Atkinson 1984).

Furthermore, Clinton presents herself as an experienced politician, thus in a way seemingly retaining the line of argument that was set in the presidential Primaries in which her experience was seen as an important advantage in comparison the Obama's relative inexperience (he was only a junior United States Senator once (from January 2005 until November 2008)). Clinton's stress on experience can be seen in the example below:

(2)

\footnotetext{
128 You know, I've been involved in politics and public life in one way or

129 another for four decades. During those forty years, our country has

130 voted ten times for President. Democrats won only three of those times.

131 And the man who won two of those elections is with us today.
}

In this example, she first of all refers to her experience, which is stressed by the extensive length of her involvement in politics. By initially using the formulation four decades (line 129), instead of the more neutral formulation forty years for instance, and by immediately repeating the length (line 129), she underlines this extensiveness further. Secondly, she implicitly refers to her role of First Lady when her husband, Bill Clinton, was president by the vague reference in one way or another (lines 128-129). She makes this reference explicit by means of her body language at the end of the fragment, when she turns to Bill Clinton who is standing in the audience and applauds him together with the audience. As such she not only presents herself as an experienced woman, but also as a wife, as such showing herself as a good example of the family metaphor that was introduced before.

On top of that, she repeatedly positions herself within family ties, both as a daughter and as a mother (e.g. line 206-208: I ran as a daughter who benefited from opportunities my mother never dreamed of. I ran as a mother who worries about my daughter's future (...)) and stresses that she 
could not have gotten so far without the support of her family (line 281-283: To my family - especially Bill and Chelsea and my mother, you mean the world to me and I thank you for all you have done.). As such she shows herself as a good example of the metaphor that was used as an argument to shift her own position and that of her supporters as united with the supporters of Barack Obama.

\subsection{Making race and gender relevant}

As the most focal point of the repositioning in this speech, Clinton draws on an interesting characteristic of her own and Obama's transportable identity, namely gender in the case of herself and race in the case of Obama. The reference to these aspects of transportable identity is first introduced by means of two parallel rhetorical questions in the fragment below:

(3)

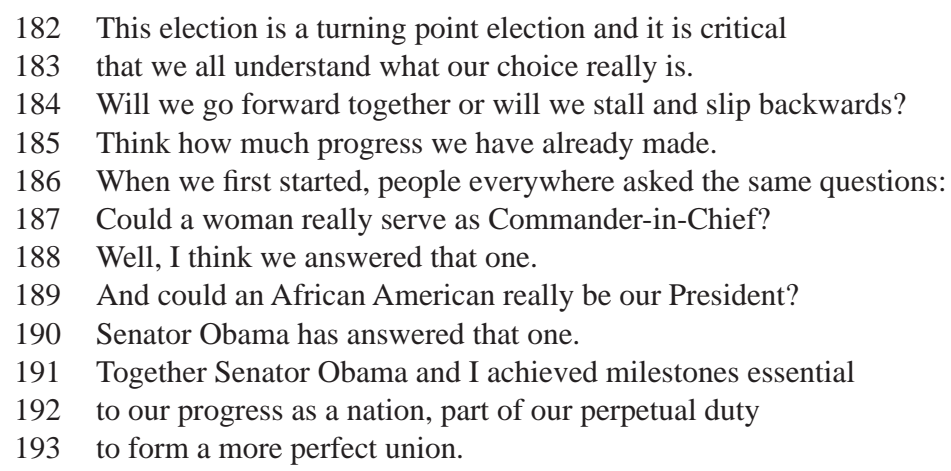

Clinton first stresses the importance of the upcoming presidential election and presents it as a dilemma in the form of a first rhetorical question (line 184). This dilemma simplifies the situation and further underlines the us-them opposition between Democrats and Republicans, represented here as progress versus decline. She then picks up this theme of progress again in the following line, thus clearly referring to all the Democrats and stressing the feats that have been achieved already, namely the fight against prejudices. These prejudices were widely present, as is indicated by the extreme case formulation people everywhere (line 186) and are voiced by means of two rhetorical questions: the first one is about Clinton herself and the gender prejudice. Interestingly, she does not voice this question in a neutral way, namely Could a woman really be our President?, but instead refers to the position of Commander-in-Chief. First of all, this is a safe option, since the answer to the neutral question would clearly be no, or we don't know yet, while now it is less explicit and thus the answer still remains open since Clinton did not have the chance to run for President. Secondly, and more importantly, this choice for one of the most typically male tasks of a president enlivens the picture that is being sketched: one immediately thinks of military parades and high-ranking officers in their uniforms. In such a picture, a woman would indeed be extraordinary, and can as such be considered a milestone, as it is qualified later in line 191.

Immediately following this first rhetorical question, Clinton introduces the race prejudice against Obama in a parallel way, except for the more factual question that is being asked (line 189). She then closes this topic by stressing the collaborative nature of her own and Obama's achievements, which is again viewed in the perspective of progress, which was identified as typical of the Democrats (line 184).

One final remark on this fragment concerns the use of pronouns. Fairclough said that "Pronouns (as always) are worth noting, especially the use of inclusive 'we'”(1995: 145). This is mainly because "pronominal reference is one of the mechanisms through which the speaker expresses both his own presence in discourse, the presence of others and relationships that he/she entertains with these others.” (De Fina 1995: 383-384). In the beginning of this fragment, (line 182-185) the we-form refers to all the members of the Democratic party. This referent changes in 
line 186, in which the we-form is narrowed down to Clinton and Obama. Then in the answer to the first rhetorical question Clinton says: I think we answered that one (line 188), in which she shifts the answer back to a personal footing (Goffman 1979) and a tentative I think, which is an explicit opinion marker (Chilton 2004: 97). Importantly, she again uses a we-form, which does not refer to the entire Democratic party anymore, but only to the segment that supported Clinton. In the part about Obama (lines 189-190), everything is formulated from an impersonal perspective, as such avoiding to hint at the opposition between Clinton and Obama's supporters in the Primaries. To further avoid this reference, the unity between Obama and Clinton is explicitly voiced again in line 191. The fragment concludes with the use of two relatively vague first person plural possessive pronouns (line 192), which can either refer to Clinton and Obama, or to the entire Democratic party. So within this short fragment, we see quite some referent shifts for the first pronoun plural (we/our). This is quite typical for political speeches, since this pronoun can "conceptualize group identity, coalitions, parties and the like, either as insiders or as outsiders" (Chilton 2004: 56) and because of this huge potential of referents (see also Poncini 2004 for instance), the exact referent often remains a bit elusive for the innocent listener. As such, opposing positions can be glossed over easily and reshifted without too much effort.

After these two aspects of the transportable identity of Clinton and Obama, namely gender and race, were introduced, Clinton only focuses on the gender aspect in the following paragraphs (lines 195-241), as such directly addressing the particular hopes and dreams of her supporters . She does that in a very explicit and rhetorical way, which I illustrate by means of one example:

(4)

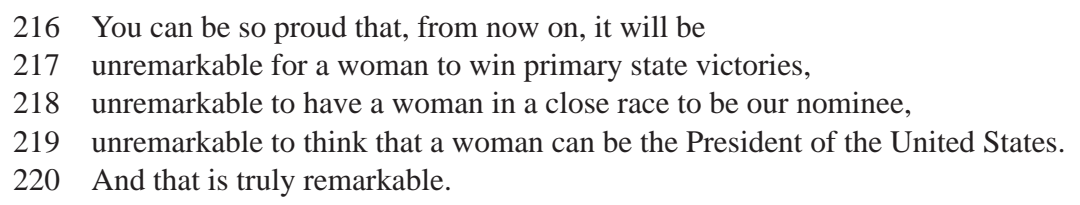

Clinton directly addresses the audience here (line 216: you) and attributes pride to them because they helped overcome this gender prejudice. This is voiced by means of a three parted list again, which is formulated in a parallel way typical of such lists (Johnstone 1983) and with increasing remarkability. The list is nicely concluded by mirroring the introductory, triple repeated unremarkable with remarkable.

Right after these paragraphs that focused solely on the gender prejudice, Clinton inserts the race prejudice again in such a way that it is hardly noticeable for the audience and even logical from a historical point of view:

(5)

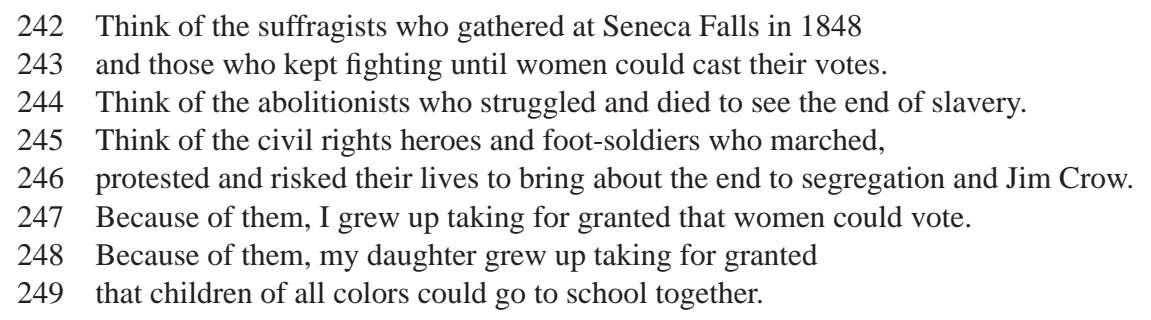

In lines 242-243, Clinton links up with the preceding paragraphs that deal with the struggle of women in America nowadays by putting this struggle in an historical perspective. She starts by referring to the first convention of the women's movement that took place in Seneca Falls in 1848 in which leading reformers, such as Elizabeth Cady Stanton and Lucretia Mott were present. Crucially, these reformers were also very active in the anti-slavery movement (Wikipedia 2009b) and thus it is not such a big step to move from the struggle of women to that of the slaves. The latter is also put in a historical perspective, starting in the $19^{\text {th }}$ century with the abolitionists (line 244) and 
moving to the $20^{\text {th }}$ century, in which some of the remaining Jim Crow laws were finally abolished (Wikipedia 2009c). Again, these examples are presented as a three parted list that is formulated in a parallel way and that is introduced by the triple repeated imperative Think of (lines 242, 244 and 245). Also within this list, another three parted list is present, namely who marched, protested and risked (lines 245-246). All these elements contribute to the highly rhetorical character of this segment of the speech.

Clinton concludes these examples by shifting from a historical perspective to a highly personal perspective, namely her own and her daughter's assumptions of equality, the former concerning men and women, the latter concerning people of different races. Both sentences are again formulated in a parallel way (because of them, $X$ grew up taking for granted that..., lines 247-248), to underline their similarity, also on a content level. By not closing off every topic first, but by mixing examples and conclusions, both elements of gender and race are put on the same level again and treated equally. As such, it is suggested that people who are willing to fight gender prejudices and support a woman as a presidential candidate, may just as well be willing to counter race prejudices and be supportive of an African American in his candidacy for President.

Immediately following this fragment, Clinton continues using the introductory parallel formulation because of them (lines 250 and 252) to link this historical and personal fight against gender and race prejudices, to the race she and Obama engaged in during the Democratic primaries:

(6)

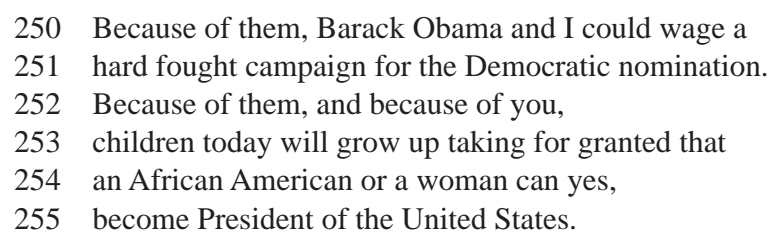

The historical perspective proposed in fragment 5 is presented here as a reason for the opportunity Obama and Clinton had to fight each other in the primaries. In this example, Clinton links up with the tough character of the campaign again (line 251), which was already raised in the beginning of the speech (see fragment1, line 95), but reframes it here as a positive culmination of the equality movements, both for women and for African Americans. In the final part of this fragment, Clinton repeats the construction initiated above (because of them, $X$ grew up taking for granted that..., lines 247-248), but rephrases it to a future tense. By doing so, she presents the Primary campaign as a historical fact, in line with the historical examples that were raised in fragment 5 , as such implicitly categorizing it as a milestone again, as was already done in fragment 3, line 191.

\subsection{Overarching categories}

In the final part of her speech, Clinton brings two overarching categories to the fore, namely being American and being human. The former had been introduced earlier in the speech, namely in the following fragment:

(7)

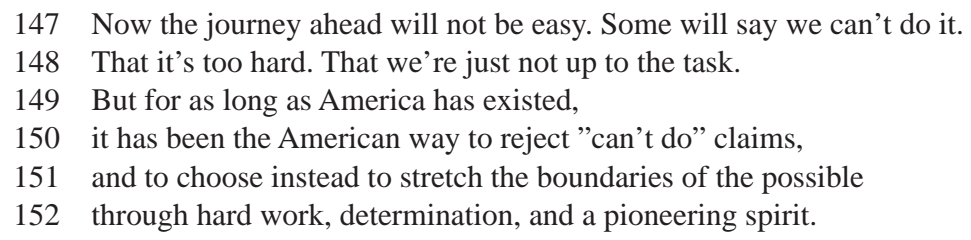

In this fragment, Clinton first addresses the difficulties they face in getting Obama elected. She does this by voicing arguments from opponents, which are again three-fold (line 147-148). These negative arguments are then countered by the American way- argument (line 150), which is also put in a historical perspective (line 149) and given further content by another three-parted list 
(line 152). This fragment is actually used as an introduction to support Obama and voice his wellknown slogan Yes we can, which she will do 4 lines later (So today, I am standing with Senator Obama to say: Yes we can., line 156). By doing so, she again explicitly presents herself as on the side of and united with Obama.

Near the end of the speech, this aspect of the American nationality is taken up again as it is linked to a category that is even more overarching, namely being human.

(8)

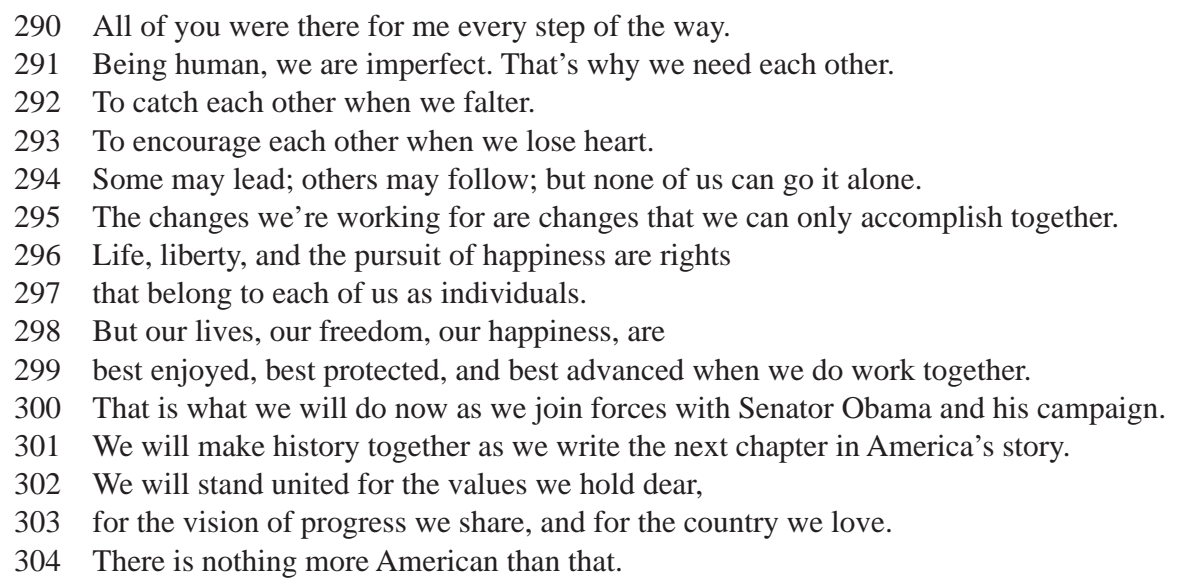

In the beginning of this fragment (lines 290-294), Clinton implicitly voices her disappointment of not winning the primaries and self-categorizes as an imperfect human (line 291). As such, she shows a more personal and slightly damaged side of herself, which makes her sympathetic in the eyes of the audience. Interestingly, this weak side is initially voiced from a personal perspective (line 290: you (= audience) were there for me (= Clinton)), but is then shifted again to a group perspective, as becomes clear from the use of the inclusive we-form, referring to herself and her supporters, which is even made more explicit by discerning between leaders (=Clinton) and followers (= supporters) (line 294).

In the middle of the fragment, some general statements of human rights are voiced (line 296297) and linked to this group identity again, as is not only shown by means of the we-form, but also by repeating the word together at the end of the sentence (lines 295 and 299). In combination with the accumulation of three-parted lists (lines 296, 298 and 299), this is a highly rhetorical part that is used as a bridge to link up with Obama's campaign again, as is shown in line 300. In this sentence, the we-form still refers to Clinton and her supporters, as they were opposed to Senator Obama and his campaign (line 300), but this referent quickly shifts in the next line to all the Democrats and it can be argued that towards the end of the fragment, the referent is even further widened to all Americans (line 303: the country we love, again the emphasized final part of a three-parted list). So again, we see quite a strategic use of the typical referential vagueness of weform (as was also raised in the discussion of fragment 3), which is used to suggest unity. By gradually widening its referent, the unity is attributed first to groups of which unity is seen as a given, namely the supporters of Clinton, to groups of which the unity is more debatable at that particular moment in history, namely all the Democrats.

\section{Conclusions}

In the analyses it was shown that Clinton heavily draws on aspects from the transportable level to construct her identity. Not only does she position herself as woman, but also as a mother, daughter and wife, as such presenting herself as emblematic of the family metaphor that is used as an argumentative device in the beginning of the speech. Furthermore, she also presents herself as a human being, with feelings of disappointment because she lost the Primaries, and as an American who fully understands the American way. 
All these elements are typical characteristics of the speaker as a person, which are indeed potentially relevant anytime, anywhere (Zimmerman 1988: 426). So next to the construction of her - typically public - situated identity, namely that of the defeated democratic candidate for presidency, Clinton draws on elements of her - more private - transportable identity as well. The evocation of these elements all work together with a clearly argumentative purpose: reconciling herself with Obama and executing an important shift in positioning (as was explained in the Methods section).

Interestingly, transportable identities typically consist of a limited number of personal characteristics; Zimmerman actually only names three, namely age, sex and race (Zimmerman 1992: 51). In this speech, also these three elements are being invoked, namely age through the reference to having experience, and sex and race by respectively referring to the women's and the anti-slavery movement. So in fact, the two main protagonists in this dataset, Clinton and Obama, differ on all three of these personal characteristics, and still these elements are drawn upon in an emphasized way to downplay the differences between them! The analyses showed however that it is through the careful formulation of the latter two characteristics and by putting them in a historical perspective, that similarity is suggested. Moreover, and most importantly from a rhetorical perspective, it categorizes the two protagonists both as representatives of powerless groups that have to fight prejudices, against gender in the case of Clinton, against race in the case of Obama. These fights of both candidates are brought to the fore as a unitary factor, both from a historical and from a personal perspective. Moreover, belonging to a powerless group puts them in the underdog position and thus stressing this fact is highly rhetorical as well. This is because the underdog position has been described as a technique for gaining sympathy (goodwill) from the audience (Andeweg /De Jong 2004). Next to sharing the underdog position, Clinton's stress on other personal characteristics they share (e.g. nationality and being human beings) further downplays the differences between them and almost seems to gloss over the fact that the speech executes an important positioning shift.

Thus it can be concluded that constructing an identity that relies heavily on aspects of the transportable identity level can be an important persuasive device. As such, it was demonstrated how ethos, in classical rhetorical terms, is discursively constructed in a speech and how it served the argumentational goal of carefully executing an important and historical positioning shift, namely from opponent to supporter of Barack Obama.

\section{References}

Andeweg, Bas A./De Jong, Jaap C. 2004: De eerste minuten: Attentum, benevolum en docilem parare in de inleiding van toespraken [The first minutes: Attentum, benevolum and docilem parare in the introductions of speeches]. Den Haag: Sdu Uitgevers.

Aristotle 4th c. BC: Rhetoric. Edition used: Rhys Roberts, W. (trans) 2004. Kessinger Publishing: Whitefish, MT.

Atkinson, John Maxwell 1984: Public speaking and audience responses: some techniques for inviting applause. In Atkinson, John Maxwell/Heritage, John (eds.), Structures of Social Action; Studies in Conversation Analysis. Cambridge: Cambridge University Press, 370-409.

Bamberg, Michael 1997: Positioning between structure and performance. In Journal of Narrative and Life History 7 , 335-342.

Bamberg, Michael/De Fina, Anna/Schiffrin, Deborah 2007: Introduction to the volume. In Bamberg, Michael/De Fina, Anna/Schiffrin, Deborah (eds.), Selves and Identities in Narrative and Discourse. Amsterdam: John Benjamins, 1-8.

Chilton, Paul 2004: Analysing Political Discourse, Theory and Practice. Routledge: London.

De Fina, Anna 1995: Pronominal choice, identity, and solidarity in political discourse. In Text 15 (3), 379-410.

De Fina, Anna 2003: Identity in Narrative, a Study of Immigrant Discourse. John Benjamins Publishing Company: Amsterdam.

De Fina, Anna/Schiffrin, Deborah/Bamberg, Michael 2006: Introduction. In De Fina, Anna/Schiffrin, Deborah/Bamberg, Michael (eds.), Discourse and Identity, Studies in Interactional Sociolinguistics 23. Cambridge: Cambridge University Press, 1-23. 
Fairclough, Norman 1995: Media Discourse. London: Edward Arnold.

Georgakopoulou, Alexandra 2007: Small Stories, Interaction and Identities. Amsterdam: John Benjamins.

Goffman, Erving 1979: Footing. In Semiotica 25 (1/2), 1-29.

Hall, Stuart 2000: Who needs ‘identity’?. In du Gay, Paul/Evans, Jessica/Redman, Peter (eds.), Identity: a reader. Sage: London, 15-30.

Hall, Christopher/Slembrouck, Stef/Sarangi, Srikant 1999: The legitimation of the client and the profession: Identities and roles in social work discourse. In Sarangi, Srikant/Roberts, Celia (eds.), Language, power, and social process: Vol. 1: Talk, work, and institutional order: Discourse in medical, mediation, and management settings. Berlin: Mouton de Gruyter, 293-322.

Johnstone, Barbara 1983: Presentation as Proof: The Language of Arabic Rhetoric. In Anthropological Linguistics 25, 47-60.

Johnstone, Barbara 1996: The linguistic individual. New York/Oxford: Oxford University Press.

Lakoff, George 1991: Metaphor and War: The Metaphor System Used to Justify War in the Gulf [online]. http://www2. iath.virginia.edu/sixties/HTML_docs/Texts/Scholarly/Lakoff_Gulf_Metaphor_1.html. (accessed 9 March 2009).

Lakoff, George/Johnson, Mark 1980: Metaphors we live by. Chicago and London: The University of Chicago Press.

Linde, Charlotte 1993: Life Stories: The Creation of Coherence. Oxford, U.K.: Oxford University Press.

Leudar, Ivan/Marsland, Victoria/Nekvapil, Jirí 2004: On membership categorization: 'us', 'them' and 'doing violence' in political discourse. In Discourse \& Society 15 (2-3), 243-266.

Ochs, Elinor 1993: Constructing Social Identity: A Language Socialization Perspective. In Research on Language and Social Interaction 26 (3), 287.306.

Pomerantz, Anita 1986: Extreme Case formulations: A way of legitimizing claims. In Human Studies 9, 219-229.

Poncini, Gina 2004: Discursive Strategies in Multicultural Business Meetings (Linguistic Insights, Volume 13). Bern: Peter Lang.

Potter, Jonathan/Wetherell, Margaret/Chitty, Andrew 1991: Quantification Rhetoric - Cancer on Television. In Discourse \& Society 2(3), 333-365.

Schiffrin, Deborah 1996: Narrative as self-portrait: sociolinguistic constructions of identity. In Language in Society 25, 167-203.

Seidl, David 2003: Metaphorical Self-Descriptions of Organizations. In Müller, Andreas P./Kieser, Alfred (eds.), Communication in Organizations, Structures and Practices. Frankfurt am Main: Peter Lang, 165-182.

Van De Mieroop, Dorien 2005: An integrated approach of quantitative and qualitative analysis in the study of identity in speeches. In Discourse \& Society 16, 107-130

Van De Mieroop, Dorien 2007: The complementarity of two identities and two approaches: Quantitative and qualitative analysis of institutional and professional identity. In Journal of Pragmatics 39, 1120-1142.

Van De Mieroop, Dorien 2008: Co-constructing identities in speeches: How the construction of an 'other' identity is defining for the 'self' identity and vice versa. In Pragmatics 18(3), 491-509.

Verschueren, Jef 2008: Intercultural communication and the challenges of migration. In Language and Intercultural Communication 8, 21-35.

Wetherell, Margaret/Maybin, Janet 1996: The distributed self: A social constructionist perspective. In Stevens, Richard (ed.), Understanding the Self. London: Sage, 219-279.

Wikipedia 2009a: Democratic Party (United States) presidential primaries, 2008 [online]. http://en.wikipedia.org/ wiki/Democratic_Party_(United_States)_presidential_primaries,_2008 (accessed 8 March 2009).

Wikipedia 2009b: Seneca Falls Convention [online]. http://en.wikipedia.org/wiki/Seneca_Falls_Convention (accessed 8 March 2009).

Wikipedia 2009c: Jim Crow laws [online]. http://en.wikipedia.org/wiki/Jim_Crow_laws (accessed 8 March 2009).

Zimmerman, Don H. 1988: On Conversation: The Conversation Analytic Perspective. In Communication Yearbook 11: published annually for the International Communication Association. Newbury Park: Sage, 406-432.

Zimmerman, Don H. 1992: Achieving Context, Openings in Emergency Calls. In Watson, Graham / Sieler, Robert M. (eds.), Text in Context, Contributions to Ethnomethodology. Newbury Park: Sage, 35-51.

Zimmerman, Don H. 1998: Identity, Context and Interaction. In Antaki, Charles / Widdicombe, Sue (eds.), Identities in Talk. London: Sage, 87-106. 


\section{To access international literature on linguistics and language that speaks volumes, start here.}

\section{ProQuest Linguistics \& Language Behavior Abstracts}

offers a world of relevant, comprehensive, and timely bibliographic coverage.

Thousands of easily searchable abstracts enhance discovery of full-text articles in thousands of key journals published worldwide, books, and dissertations, plus citations to reviews of books and other media. This continuously growing collection includes over 410,000 records, with monthly updates and backfiles to 1973 — plus browsable indexes and a thesaurus through the ProQuest Illumina ${ }^{\mathrm{T}}$ interface.

So whatever your quest, start here with ProQuest Linguistics \& Language Behavior Abstracts

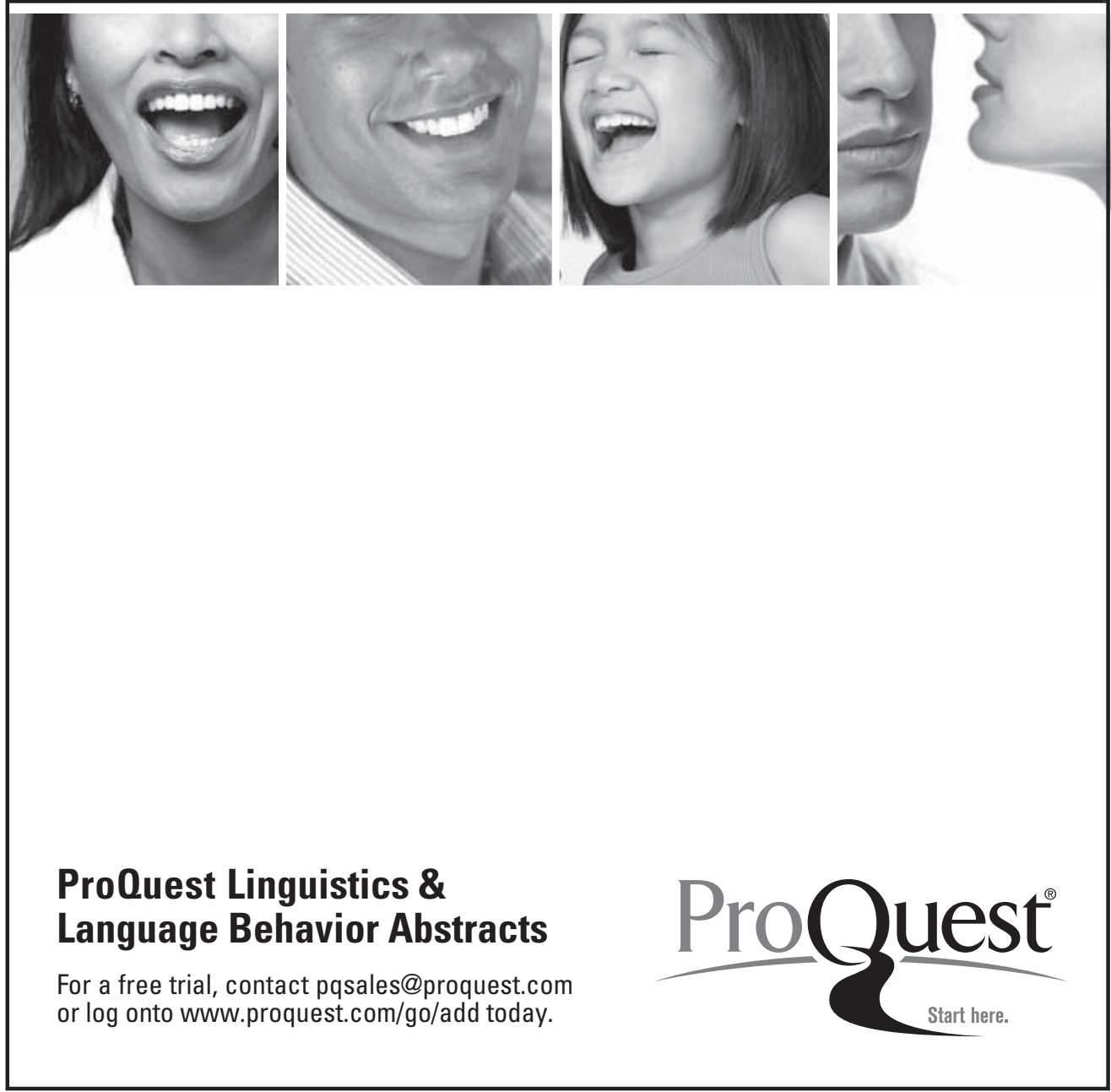

